it had led to important results both in the stratigraphy and palæontology of the Devonian and Carboniferous rocks of that region. In Aberdeen, field-work on the Old Red Sandstone of various areas of north-east Scotland, the Orkneys and Shetlands and on their faunas has been actively continued, along with investigations of the morphology and relationships of the various groups of fishes and the origin of tetrapod structures. This work has become of international repute. In 1941 the University of Aberdeen conferred on him the degree of D.Sc. In the following year Dr. Westoll was elected a fellow of the Royal Society of Edinburgh and a member of the New York Academy of Seiences. In 1947 he was invited to the Princeton Bicentenary Celebrations to participate in the conference on palæontology, genetics and evolution, and afterwards to the Paris conference on palæontology.

\section{Chemistry at University College, Swansea : Prof. J. E. Coates, O.B.E.}

THe pending retirement of Prof. J. E. Coates from the chair of chemistry marks the close of an important period in the history of the University College of Swansea, for, of the professors of scientific subjects appointed at the time of its foundation, he is the last remaining in the service of the College. After a brilliant career as student at Bangor, in London and at Karlsruhe, and distinguished service during the First World War in the Royal Naval Air Service, he was in 1920, when a member of the staff of the University of Birmingham, called to the professorship of chemistry at the newly established Swansea College of the University of Wales. It then fell to his lot to start, build up and maintain one of the major departments of the College, and the magnitude of his success in this arduous and responsible labour is demonstrated by the rapid advancement of the Chemistry Department to its present prosperous condition, and great service to the important industrial area in which it is situated. Under his direction, a foremost feature has been activity in research in physical chemistry, in which branch he was trained during his early investigations under the great masters, Ramsay and Haber. Among his studies while at Swansea have been the physical and chemical properties of hydrogen cyanide and its solutions. His past and present students, his colleagues and his numerous friends will all wish Prof. Coates many years of further fruitful activity.

\section{Dr. C. W. Shoppee}

DR. C. W. SHOPPEE has been appointed to the chair of chemistry in the University of Wales, tenable at University College, Swansea, in succession to Prof. J. E. Coates. Dr. Shoppee's earliest research work was carried out in 1923 at the Imperial College with Dr. C. K. Ingold and the late Sir Jocelyn Thorpe. In 1924, he accompanied Prof. Ingold to the University of Leeds, and in 1928, after having held an 1851 Senior Studentship, was appointed to the staff of that University. In 1939, he was elected to a Rockefeller Research Fellowship, which he chose to hold in the laboratory of Prof. T. Reichstein at the University of Basle. In 1944, he was appointed to a readership in chemistry in the University of London, tenable at the Royal Cancer Hospital (Free). Dr. Shoppee is distinguished for his researches on the mechanism and kinetics of tautomeric change, and for his work on the hormones of the adrenal cortex, which led to the establishment of the detailed structures of these physiologically important compounds. At the Chester Beatty Research Institute of the Royal Cancer Hospital (Free), he has applied his special knowledge of the microchemical and chromatographic investigation of natural products to the isolation and identification of the endogenous carcinogenic substances present in human tissues. In the steroid field, he has gained an intermational reputation, and his most recent work involves application of the new conceptions of the mechanism of organic reactions to the determination of chemical configuration in natural products, an ultimate aim being to illuminate the highly specific relationship between chemical configuration and physiological activity.

\section{Engineering at University College, Swansea : Mr.} L. J. Kastner

Mr. L. J. KASTNER, of the Department of Engineering, University of Manchester, has been elected to the chair of mechanical engineering at University College of Swansea, which became vacant by the appointment in 1946 of Prof. R. N. Arnold to the regius professorship of engineering in the University of Edinburgh. Mr. Kastner took the Mechanical Sciences Tripos at Cambridge in 1934. Following a period of practical workshop training with Messrs. Davis and Metcalfe, of Romiley, he went to the University of Manchester to do research on internal combustion engineering, which led to the degree of M.Sc. In 1938, he was appointed to the staff of the Engineering Department at Manchester, and in $\mathbf{1 9 4 5}$ became senior lecturer in the Department. While there he has been responsible for the advanced teaching in thermodynamics at Manchester and has also taken a large part in running the Engineering Laboratories. $\mathrm{He}$ has been actively engaged in research, more especially in the field of internal combustion engineering, and has published several original papers dealing with various aspects of this work. It is of interest to note that Mr. Kastner is now the third in the family line of university professors, his grandfather and father having in turn held the chair of French in the University of Man. chester.

\section{Department of Scientific Research, India}

THE Government of India has created a Department of Scientific Research with effect from June 1. The Department will be in the charge of the Prime Minister of India, and Sir Shanti Bhatnagar, director of scientific and industrial research, has been appointed secretary and principal executive officer. The Department will take over the work of the Board of Research on Atomic Energy and the Council of Scientific and Industrial Research. The latter body, although attached to the new Department, will retain its unofficial character and will continue to function as before. The new Department will deal also with scientific advice to Government departments, ad hoc scientific research in universities and research institutions, research scholarships in applied scientific subjects, international scientific unions, scientific liaison offices, the Scientific Consultative Committee and such other subjects as may be transferred to it. The Department will co-ordinate the scientific activities of the other Ministries, and in this work it will be assisted by a co-ordination committee consisting of eminent men of science. 